\title{
Pengaruh Pembelajaran Daring Mahasiswa Dimasa Covid 19 Dalam Tugas Mempelajari Dan Menghafal Ayat-Ayat Alquran
}

\author{
${ }^{1}$ Bashori Hasan, ${ }^{2}$ Muhammad Habib, ${ }^{3}$ Cindy Mutiara Utami, ${ }^{4}$ Devania Agelita Andani \\ PAI/ Fak Keperarawatan, Fak Kebidanan dan Kesehatan \\ Universitas Duta Bangsa Surakarta \\ Email Korespondensi : Bashorihasan@yahoo.com
}

\begin{abstract}
Abstrak
Pandemi Covid 19 menyebar sejak akhir tahun 2019 hingga kini di beberapa wilayah dengan kasus yang berbeda, terhitung 193 negara berjuang dengan keras untuk melawan covid yang tidak pandang bulu. Wuhan adalah salah satu kota di China sebagai tempat pertama kali virus ditemukan, sebelum virus ini lalu berstatus pandemi. Tentu sangat berpengaruh terhadap sosial ekonomi, khususnya bidang pendidikan, pelaksanaan sistem pembelajaran pada satuan pendidikan mengalami perubahan bentuk operasional yaitu intruksi social distancing, hingga berujung pada himbauan lockdown, sehingga model pembelajaran hampir di seluruh Indonesia dengan Model daring mulai daari lembaga pendidikan hingga Instansi Pemerintah. Penelitian ini menggunakan metode diskrptif kualitatif karena jauh lebih subyektif dalam pembelajaran daring di Universitas Duta Bangsa Surakarta yang diputuskan pembeljaran dari rumah. Subyek terdiri dari 2 dosen dan 2 mahasiswa Universitas Duta Bangsa Surakarta. Dengan aplikasi E-Learning UDB, Zoom, Google Meet, Whatsap, vidio call email dll, walaupun terdapat beberapa kendala diantaranya, sinyal internet, kuota , serta tidak bisa bertanya kepada dosen dengan leluasa.
\end{abstract}

Kata kunci : Pengaruh:Covid 19 Dalam Pembelajaran Daring Mahasiswa Dimasa Covid 19 Dalam Mempelajari Al Quran

\section{Abstract}

The Covid 19 pandemic has spread since the end of 2019 until now in several regions with different cases, including 193 countries struggling hard to fight covid indiscriminately. Wuhan is one of the cities in China where the virus was first discovered, before this virus became a pandemic. Of course, it is very influential on socio-economic conditions, especially in the field of education, the implementation of the learning system in education units has changed its operational form, namely social distancing instructions, which led to the call for lockdown, so that learning models are almost all over Indonesia with online models ranging from educational institutions to government agencies. This study uses a qualitative descriptive method because it is much more subjective in online learning at Duta Bangsa University Surakarta which is decided to learn from home. The subjects consisted of 2 lecturers and 2 students at Duta Bangsa University, Surakarta. With the UDB E-Learning application, Zoom, Google Meet, Whatsap, video call, email, etc., although there are several obstacles including internet signal, quota, and cannot ask lecturers freely.

Keywords: Influence: Covid 19 In Online Learning Students During The Covid 19 Era In Studying The Qur'an

\section{PENDAHULUAN}

Pendidikan pada masa-masa

Rasulullah Muhammad saw dan pada masamasa sahabat Bermula dari halaqah (majlis ilmu berbentuk lingkaran) dari sanalah lalu di jaman beliau Rasulullah menggunakan masjid sebagai pusat kegiatan umat Islam, yang meliputi berbagai disiplin ilmu bahkan masjid digunakan sebagai pusat pemerintahan, oleh karenanya sudah saatnya kita mengikuti jejak Beliau Muhammad saw untuk menjadikan masjid sebagai sarana yang tepat untuk mempelajari Al-Qur'an. Rasulullah pernah bersabda " akan datang pada suatu masa pada umatku tatkala aku sudah tiada, tidak akan kekal agama Islam kecuali tinggal namanya, dan Al-Qur'an tinggal tulisanya, pendidikan agama telah ditinggalkan, dan pada masa itu banyak dari umatku berlomba-lomba membangun masjid akan tetapi kosong dari mengingat Allah, dan sejelek-jelek masa itu adalah dari ulama-ulama timbul fitnah, dan akan kembali fitnah itu kepada mereka, dan jika semua itu telah terjadi maka itulah tandatanda kiamat.

Pada alinea keempat Undang-undang Dasar 1945 disebutkan bahwa pemerintah Negara Republik Indonesai berkewajiban untuk "mencerdaskan kehidupan bangsa", dan diperjelas lagi dalam pasal 31 ayat 1 dinyatakan "bahwa setiap warga negara berhak mendapat pendidikan." Pendidikan adalah merupakan alat yang paling penting untuk mengembangkan potensi kehidupan manusia, baik intelegensia, kreativitas, maupun akhlak al-karimah melalui kegiatan 
bimbingan, pengajaran, dan latihan. Aktivitas pendidikan terkait dengan tujuan pembentukan manusia seutuhnya dalam rangka memajukan peradaban. Sebagaimana tertuang dalam undang-undang Sistem Pendidikan Nasional No. 20 tahun 2003, Bab II, pasal 3 dirumuskan bahwa:

"Pendidikan nasional berfungsi
mengembangkan kemampuan dan
membentuk watak serta peradaban
bangsa yang bermartabat dalam rangka
mencerdaskan kehidupan bangsa,
bertujuan untuk berkembangnya potensi
peserta didik agar menjadi manusia
yang beriman dan bertakwa kepada
Tuhan Yang Maha Esa, berakhlak mulia;
sehat, berilmu, cakap, kreatif, mandiri,
dan menjadi warga negara
yang demokratis serta bertanggung
jawab.

Jelaslah disini bahwa pemerintah dan masyarakat harus bahu membahu dalam melaksanakan pendidikan, yang diawali dengan pemberantasan buta aksara. Karena walaupun pemerintah sudah menetapkan program wajib belajar 9 tahun dan program pemberantasan buta aksara seperti Program Keaksaraan Fungsional (Program KF), namun demikian programprogram tersebut belum berhasil menurunkan besarnya buta aksara sehingga sampai saat ini buta aksara tetap saja masih tinggi. Padahal tekad pemerintah pada tahun 2005 lalu mencanangkan Program Percepatan Pemberantasan Buta Aksara yang ditargetkan tuntas pada tahun 2009.

Berdasarkan data BPS tahun 20032004, posisi kebutaaksaraan penduduk Indonesia usia 10 tahun ke atas sebesar 15.533.271 orang, terdiri atas perempuan sebanyak 10.643 .823 orang (67\%) dan lakilaki sebanyak 5.042.338 orang $(32,1 \%)$. Pada usia 10-44 tahun sebesar 4.410.627 orang. Usia 15-44 tahun sebesar 3.986.187 orang. Angka buta aksara tersebut masih akan bertambah, mengingat angka tingkat putus belajar pada kelas-kelas awal (1-3) SD/MI saat ini masih 200.000 s.d. 300.000 per tahun. Khusus di bidang pendidikan, data susenas 2003 menunjukan bahwa penduduk perempuan usia 20 tahun ke atas yang tidak/belum pernah sekolah jumlahnya dua kali lipat penduduk laki-laki 911,56\% berbanding 5,43\%). Penduduk perempuan yang buta aksara sebesar 12,285, sedangkan laki-laki 5,82\% atau dengan kata lain bahwa jumlah buta aksara pada perempuan lebih banyak 2 samapai 3 kali lipat dari laki-laki.

Dalam Islam jelas bahwa perintah untuk membaca dimulai dari pertama kali Rasulullah diutus oleh Allah menjadi rasul dan menerima wahyu pertamnaya yaitu sural al-Alaq ayat 1-5 :

"Bacalah dengan nama Tuhanmu yang telah menciptakan. Dia telah menciptakan manusia dari segumpal darah. Bacalah Tuhanmu Yang Maha Pemurah. Yang Mengajar manusia dengan perantaraan kalam. Dia mengajarkan kepada manusia apa yang tidak diketahui."

Dalam sebuah hadis Rasulullah saw. Bersabda :

"Sebaik-baik kalian adalah iapa yang mempelajari Al-Qur'an dan mengajarkannya (HR. Al-Bukhari).

Setelah menteri pendidikan mengeluarkan Surat Edaran Nomor 3 Tahun 2020 Tentang Pencegahan Corona Virus COVID 19 pada satuan pendidikan yang menyatakan bahwa meliburkan sekolah dan perguruan tinggi,yang hal ini dilakukan untuk memutus mata rantai penyebaran COVID 19, yang berpengaruh luas terhadap dunia pendidikan dari tingkat sekolang dasar hingga perguruan tinggi. Tidak terkecuali dengan surat edaran pemerintah yang sangat viral dimasa COCID 19 yaitu surat Edaran NO SE , 21 Tahun 2021 yang dikeluarkan oleh Kementrian Agama RI, yang ditujukan kepada :

1. Pejabat Pimpinan inggi madya

2. Pejabat Pimpinan Tinggi Pratama Pusat

3. Rektor/Ketuan PerguruanTtinggi

4. Kepala Kantor Wilayah Kementrian Agama Wilayah Provinsi

5. Kepala Kantor Kementrian Agama $\mathrm{Kab} / \mathrm{Kota}$

6. Kepala Madrasah/Kepala Satuan Pendidikan Keagamaan 
7. Kepala Kantor Urusan Agama Kecamatan

8. Penghulu dan Penyuluh Agama

9. Pegawai Aparatur Sipil Negara Pada Kemetrian agama

10. Pimpinan Organisasi Kemasyarakatan

11. Pengurus dan Pengelola Tempat Ibadah, dan

12. Umat Beragama di Seluruh Indonesia

Surat Edaran NO. 21 Tahun 2021 itu

berisi Tentang Pelaksanaan kegiatan Peribadatan/Keagamaan ditempat ibadah pada masa pemberlakuan pembatasan kegiatan masyarakat level 4 dan level 3 Corona Virus Disease 2019. Dengan tujuan untuk memberikan panduan beribadah yang sejalan dengan protokol Kesehatan, sekaligus untuk mencegah, mengurangi, penyebaran dan melindungi masyarakat dari Risiko Covid 19. Untuk itu peraturan ini tentu harus di taati baik dari lembaga pemerintah maupun swasta tidak terkecual bagi dunia pendidikan baik perguruan Tinggi Negeri maupun Perguruan Tinggi Swasta, harus ikut berpartisipasi dan ikut membantu memutus rantai penularan Covid 19 dan menerapkan prokes yang di anjurkan oleh pemerintah, sehingga seluruh masyarakat Indonesia akan merasakan ketenangan dan kenyamanan dalam menjalani kehidupan sehari-hari, apalagi para mahasiswa di perguruan tinggi harus menjadi garda terdepan dalam memberi contoh untuk mengurangi penularan yang serius virus Corona Covid 19 ini.

Diantara perguruan tinggi yang kena imbasnya adalah Universitas Duta Bangsa Surakarta, peraturan atau kebijakan yang diputuskan oleh pemerintah diikuti pula oleh pimpinan atau Rektorat Universitas Duta Bangsa dengan harapan besar bisa mengurangi penyebaran COVID 19 yang semakin hari semakin bertambah angka kematian maupun angka penularan.

Pembelajaran online (E-leraning) meliputi berbagai aplikasi dan proses seperti computer-based learning, webblearning, Scology, virtual classroom, virtual zoom, wastshap dan aplikasi lainya (dakwah, 2017). Pada dasarnya pembelajaran online ini. Ini dilakukan untuk mengganti kegiatan pembelajaran secara langsung (Rizqon Halal Syah Aji,
2020). Haryono dalam Waryanto mengatakan Pembelajaran Online sebenarnya memiliki beberapa kelemahan yakni membutuhkan insfranstruktur yang memadai, kmunikasi melalui internet terdapat berbagai kendala dan kekurangan. Meskipun demikian pembelajaran online dapat dikatakan efektif apabila mahasiswa aktif dapat mencapai tujuan pembeljaran dan mahasiswa aktif dengan adanya interaksi antara dosen dan mahasiswa dalam pembelajaran tersebut tidak tidak berpusat pada dosen saja. Masa pandemi covid 19 mengharuskan masyarakat untuk lebih ketat dalam menjaga kesehatan , jaga jarak, sering cuci tangan dan tentunya mengurangi interaksi diluar rumah jika memang tidak penting. Semenjak maret 2020, Universitas Andalas telah memulai sistem perkuliahan secara daring(dalam jaringan), atau disebut kuliah online. Kuliah online ini hanyalah metode perkuliahan, yang mana mata kuliah dan proses belajarnya saja yang berbeda dari yang biasanya.

Kuliah daring adalah sistem perkuliahan yang memanfaatkan akses internet sebagai media pembelajaran yang dirancang dan ditampilkan dalam bentuk modul kuliah, rekaman video, audio atau tulisan oleh pihak akademi/universitas. (wikipedia)

Semenjak pandemi covid-19, metode belajar online merupakan langkah alternatif terbaik sejauh ini demi berjalannya perkuliahan dikampus. Tentunya metode belajar online juga memiliki kelebihan dan kekurangan, diantaranya :

\section{Kelebihan kuliah daring}

1. Hemat Biaya Transportasi

Mahasiswa yang biasanya mesti datang langsung kekampus untuk mengikuti perkuliahan, namun sekarang tidak mesti datang kekampus lagi, secara otomatis biaya yang biasa dikeluarkan untuk beli bensin/ongkos transportasi umum tidak ada lagi.

2. Hemat Waktu dan Tenaga

Tentunya waktu yang dihabiskan dengan kuliah secara tatap muka lebih banyak dibandingkan dengan kuliah daring, dikarenakan pergantian jam antara mata 
kuliah dengan mata kuliah yang lain terkadang memiliki jeda yang lama, sehingga mengharuskan untuk menunggu dikampus.

3. lebih santai dan terhindar dari bising Penerapan kuliah daring lebih terasa tenang, lebih santai bisa dilakukan dirumah, dikamar, dicafe atau dimanapun asalkan akses internet dan perangkat memadai.

Kelemahan belajar daring

1. Wajib Akses Internet

Kuliah online sudah dipastikan membutuhkan akses internet, dengan berbagai mediator yang ada seperti laptop, ipad, smartphone, dll.

2. Penyampaian dan Penerimaan Materi Tidak Maksimal

Proses belajar mengajar tidak selamanya mudah dimengerti oleh mahasiswa, apalagi jika prosesnya hanya dengan daring, tentunya tingkat fokus mahasiswa dan penerimaan materi yang disampaikan tidak lebih baik dari kuliah tatap muka.

3. keterbatasan dalam praktek dan tanya jawab

Untuk mata kuliah teori memang tidak akan terlalu bermasalah jika dihadapkan dengan kuliah online, namun untuk mata kuliah praktek, maka kuliah online tidaklah menjadi solusi akan hal ini, dan dampak dari keadaan seperti ini, pengetahuan dan pemahaman mahasiswa tentang materi kuliahnya tidak maksimal.

Jika ditarik kesimpulan, bahwasannya : metode kuliah online maupun metode kuliah tatap muka punya keunggulan dan kelemahan masing-masing yang mana penerapannya mesti dilihat dari kemaslahatan yang ada, serta kembali kepada tujuan dan target dari jenis mata kuliahnya. (Beni Adri Yassin, 2021)

Pembelajaran serta minat mahasiswa dalam mengikuti perkuliahan merupakan keharusan yang harus ada dan harus mempunyai semangat yang tinggi untuk selalu tidak ketinggalan dalam mengikuti setiap mata kuliah yang harus diambil, baik sks yang berhubungan dengan fokus jurusan yang diambil maupun bidang yang lain yang menjadi mata kuliah yang juga wajib harus dipenuhi, jika semangat ini bisa terpenuhi tentu perkuiaahan akan semakin baik, begitu sebaliknya jika semangat mahasiswa lemah tentu tentu kulailats perkulihaan juga semakin lemah.

Dengan mengacu pada hal tersebut peneliti ingin meneliti seberapa besar pengaruh COVID 19 terhadap semangat belajar online atau daring mahasiswa di Universitas Duta Bangsa Surakarta dalam melaksanakan Tugas mata kuiah Agama Islam dalam kiat-kiatnya menghafal ayat-ayat $\mathrm{Al}$ quran.

Adapun rumusan masalahnya dalam penelitian ini adalah :

1. Bagaimana pengaruh pembelajaran online atau daring terhadap mahasiswa Universitas Duta Bangsa terhadap tugas kuliah Agama Islam dalam menghafal ayat-ayat $\mathrm{Al}$ quran.

2. Bagaimana dampak Mahasiswa Universitas Duta Bangsa saat harus menyelesaikan tugas mata kuliah agama Islam dalam menghafal ayat-ayat Alquran.

Penelitian ini dilakukan dan dimaksudkan untuk tujuan mengetahui fenomena apa yang terjadi ketika dosen memberikan tugas yang harus diselesaikan mahasiswa dirumah, apa yang terjadi pada mahasiswa efektif atau tidak, ilmu yang diserap efektif atau tidak, semangat atau antusias belajar dengan online berjalan lancar atau sebaliknya.

Berdasarkan rumusan masalah diatas maka ada variabel dependenya adalah minat belajar (Y). Sedangkan variabel independen adalah Pengaruh pembelajaran Online atau daring.

\section{METODE PENELITIAN}

Penelitian ini menggunakan metode deskriptif kualitatif . Penelitian kualitatif Merupakan penelitian yang digunakan untuk meneliti kondisi obyek yang alamiah dimana peneliti sebagai instrumen kunci dan hasil penelitianya lebih lebih menekankan makna pada generalisasi atau penelitian yang berllandaskan filsafat post positivisme (Ericha Windhiyana Pratiwi, 2020). Penelitian 
deskriptif merupakan penelitian yang dilakukan untuk mendeskripsikan suatau variabel, baik satu variabel atau lebih (independen) tanpa membuat perbandinan, atau menghubungkan variabel satu dengan variabel lainya. (Rizqon Halal Syah Aji, 2020). Di dalam penelitian ini data yang dikumpulkan berupa kalimat dan penjabaran jawaban dari subjek yang dilakukan dengan cara angket. Pengambilan subyek menggunakan metode Snowball trowing. Subyek ini terdiri dari 2 dosen dan 2 mahasiswa. Instrumen terdiri dari peneliti sebagai Instrumen utama dengan instrumen bantu. Data dalam penelitian ini berupa angket online melalui Whattshapp yang merupakan jawaban dari subjek merupakan deskripsi dari Pengaruh Pembelajaran Daring mahasiswa dimas COVID 19 dalam tugas mempelajari dan menghfal ayat-ayat Alquran di perguruan tinggi Universitas Duta Bangsa Surakarta.

digunakan:

Inilah pedoman wawancara yang

1. Teknis apa yang digunakan untuk pelaksanaan pembelajaran daring saat pandemi COVID 19 ?

2. Aplikasi apa yang digunakan dosen untuk melaksanakan tugas mempelajari dan meghafal ayat-ayat $\mathrm{Al}$ quran secara online ?

3. Bagaimana pelaksanaan pembelajaran online dengan menggunakan aplikasi yang ada?

4. Apa kendalanya yang dihadapi saat mengerjakan tugas mempelajari dan dan menghafal ayat-ayat Alquran ?

5. Mengapa mahasiswa harus mengerjakan tugas mempelajari dan menhafal ayat ayat $\mathrm{Al}$ quran ?

Menurut hasil diskusi atau wawancara online antara dosen 1 dan 2 kepada mahasiswa 1 dan 2 mengatakan hampir ada jawaban yang serupa antara mahasiswa 1 dan mahasiswa 2, yang mengatakan bahwa pembelajaran online sebenarnya sudah efektif dan jelas walau dirasa ada saatnya internet sinyalnya putus putus, akan tetapi dosen menyampaikan bila mahasiswa belum jelas diminta untuk menyampaikanya, sehingga dosen bisa menjelaskanya kembali.

\section{HASIL DAN PEMBAHASAN}

Dari hasil penelitian yang didapat menunjukkan bahwa pemebelajaran daring mahasiswa dimasa COVID 19 dalam tugas mempelajari dan menghafal ayat-ayat Alquran yaitu belajar dan mengerjakan tugas dirumah dengan menggunakan pembelajaran dengan sistem online, terkhusus untuk mata kuliah agama Islam di Universtas Duta Bangsa, selain mempelajari materi agama Islam uang luas juga diwajibkan dan sebagai satu diantara beberapa syarat kelulusan serta pengambilan ijasah, di Universitas Duta Bangsa Surakarta , Mahasiswa yang lulus harus memenuhi persyaratan, diantaranya harus, bisa menjadi imam sholat ditempat mhasiswa tinggal, juga harus bisa azan dan iqamah bagi mahasiswa tidak wajib bagi mahasiswi, juga harus bisa menjadi imam sholat jenazah di tempat tinggal para mahasiswa dan mahasiswi, dan juga harus menyetorkan hafalanya ke dosen yang mengampu mata kuliah agama Islam, paling tidak wajib harus hafal minimal 20 surat pendek dan beberapa surah panjang pilihan, oleh karenanya menurut dosen 1 dan dosen 2 sepakat tugas bisa terlaksana dan bisa dilaksanakan dengan sistem online, mahasiswa 1 dan mahasiswa 2 menyampaikan pendapatnya, bahwa pemebelajaran online atau daring dirumah dirasa nyaman karena bisa dilaksanakan kuliah dirumah sendiri hemat biaya transportasi, uamg jajan dan tidak capek, akan tetapi ketika baik dosen 1 dan 2 menanyakan apa kendalnaya, baik mahsiswa 1 dan mahasiswa 2 hampir sama jawabanya yaitu kalau perkuliaahan dilaksanakan secara daring atau dirumah terus menerus juga bosan karena ternyata juga menggunakan kuota yang cukup, juga sinyal yang tidak stabil yang mengganggu saat dosen menyampaikan atau memberi pertanyaan tidak terdengar jelas, dan dengan aplikasi menggunakan E-Learning UDB WA, google classroom, google meet,, juga terkhusus di mata kuliah agama untuk setor hafalan banyak aplikasi tambahan diantaranya dengan vidio call, Wasthsaapp, e-mail , juga 
google drive. Berikut cuplikan atau rekaman wawancara saat berlangsung :

D : Teknis apa yang digunakan untuk pelaksanaan pembelajaran daring saat pandemi COVID 19?

M! Pemebelajaran dilakukan di rumah saja dengan sistem online

D : Aplikasi apa yang digunakan dosen untuk melaksanakan tugas mempelajari dan meghafal ayat-ayat $\mathrm{Al}$ quran secara online ?

M1 : Para dosen menggunakan aplikasi yang berbeda -beda ada yang menggunakan E-Learning UDB, google meet, Washaapp dll.

D : Bagaimana pelaksanaan pembelajaran online dengan menggunakan aplikasi yang ada?

M1 : Sangat baik saat sinyal internet bagus

D. : Apa kendalanya yang dihadapi saat mengerjakan tugas mempelajari dan menghafal ayat-ayat Alquran ?

M1. : Saat -saat dosen menyampaikan pertanyaan dan penjelasan terkadang tidak jelas dan tidak faham, karena sinyal yg jelek putus-putus dan terkadang kuota habis begitu cepat.

D : Mengapa mahasiswa harus mengerjakan tugas mempelajari dan menhafal ayat -ayat Al quran ?

M1. : Karena Wajib sebagai satu diantara syarat kelulusan di Universitas Duta Bangsa.

Lain lagi dengan penuturan mahasiswa 2 yang menyatakan bahwa pembelajaran online untuk menyelesaikan tugas mata kuliah agama Islam bisa dikatakan belum efektif dikarenakan ayat- alquran harus dipahami dengan mengerti hukum tajwid dan baiknya harus tatap muka dengan dosen secara langsung di kampus , namun karena pembelajaran dilaksanakan disaat pandemi COVID 19 , maka Sistem daring dan online dirasa efektif juga namun kendalanya juga sangat banyak diantaranya adalah sinyal yang sering putus putus juga disisi lain sangat boros bagi mahasiswa ketika kuota cepat habis, tentu menjadi kendala yang sangat besar tatkala harus pergi membeli pulsa lebih dahulu disaat pembelajaran berlangsung. Untuk pertanyaan M2 ini dengan perta 19 dalam tugas mempelajari dan menghafal ayatayat Alquran di Universitas Duta Bangsa Surakarta terdapat kelebihan dan kekurangan , diantara kelebihanya adalah pembelajaran dan perkuliahan tetap berjalan dengan baik sesuai dengan harapan dan kekurangan atau kendala yang di alami mahasiswa lebih kepada gangguan koneksi internet yang terkadang susah di akses, namun demikian dengan sistem E- learning UDB, google meet, google classroom, zoom, google drive, Whatshapp $d l l$, sebagai sarana untuk mengirimkan baik materi , tempat berdiskusi online yang bertujuan agar perkuliaahan tetap berjalan dan berlangsung walau ierdapat kendala sinyal internet.

Dilihat dari hasil angket dan wawancara dengan mahasiswi dapat dikatakan cukup untuk menjembatani perkuliahan yang belum usai atau harus tetap berlangsung di Universitas Duta Bangsa Surakarta, sebagai pengganti kuliah dengan tatap muka, walaupun dirasa masih banyak kendala yang dihadapi, namun masih tetap berjalan dengan baik dengan menggunakan aplikasi E-Learning UDB, E-mail, zoom, google meet, Whatshapp, googlr drive.

\section{KESIMPULAN}

Berdasarkan hasil penelitian dan hasil pembahasan tersebut di atas bahwa pengaruh pembelajaran daring mahasiswa dimasa pandemi COVID 19 dalam tugas mempelajari dan menghafal ayat-ayat Alquran , bisa dilakukan dengan baik dan berjalan efektif walau masih banyak kendala yang dihadapi , saat menghadapi pengaruh COVID 19 yang begitu besar pengaruhnya terhadap dunia pendidkan pembelajaran yang seharusnya dilaksanakan dimeja sekolah atau kampus harus dipindah dirumah masing masing siswa, demi untuk memutus rantai penularan COVID 19 dan menyelamatkan generasi bangsa Indonesia , oleh karena itu agar perkuliahan agar tetap berjalan maka Universitas Duta Bangsa Surakarta, menggunakan fasilitas aplikasi yang tersedia, diantaranya $E$ Learning UDB, google meet, google 
classroom, Whatshapp, zoom, google drive $d l l$, dengan demikian perkuliahan tetap berjalan dengan baik dan dosen dapat dengan berfariasi menggunakan fasilitas aplikasi yang ada untuk mngimkan baik pertanyaan, file atau materi pembelajaran yang cukup cepat tersampaikan.

\section{SARAN}

Dari hasil penelitian dan wawancara yang telah dilakukan, maka terdapat saran yaitu apabila pembelajaran di Universitas Duta Bangsa Surakarta di semester kedepan masih [pandemi COVID 19 dan masih menjalankan pembelajaran secara daring atau online, maka baiknya pihak manajemen Universitas Duta Bangsa Surakarta memberikan Subsidi Kuota kepada para mahsiswa dan mahasiswinya , yang mencukupi serta memilihkan kartu yang jaringan internetnya stabil, sehingga mahasiswa terasa terbantu dan semangat untuk mengikuti pembelajaran yang tetap dilaksanakan oleh Universitas Duta Bangsa Surakarta.

\section{UCAPAN TERIMA KASIH}

Ucapan terimakasih tak lupa kami sampaikan kepada civitas akademik Universitas Duta Bangsa Surakarta, Fakulyas kesehatan dan Kebidanan dan bebagai pihak yang terlibat dalam penelitian ini yang telah memberikan waktunya dan pikiran dimasa COVID 19 ini telah membantu menyelesaikan jurnal ilmiah ini.

\section{DAFTARA PUSTAKA}

Departemen Agama RI, (2002) Mushaf AlQur'an Terjemah, Jakarta: Pena Pundi Aksara

Ericha Windhiyana Pratiwi.(2020), Dampak Covid 19

Fadlullah, (2008) Orientasi Baru Pendidikan Islam, Jakarta: Diadit Media

https//pustaka.unand.ac.id/component/k2/item /231-kuliah online-daring.

Humam, As'ad, (2000) Buku Iqro; Cara Cepat Belajar Membaca Al-Qur'an, edisi revisi, Yogyakarta: Balai Litbang LPTQ Nasional
Jurnal of Education and Learning (EduLearn),6(1).https:doi.org/10.115 91/edulearn. V6i1.190. Kementrian agama RI, SE, 21 tahun 2021.

Laporan Kementerian Negara Pemberdayaan Perempuan tentang Rencana Aksi Nasional (RAN) Pemberantasan Buta Aksara Perempuan (PBAP) tahun 2006, Jakarta

Laporan PAP Bidang Pendidikan tentang Program Penuntasan Buta Aksara Latin dan Al-Qur'an dengan menggunakan metode Iqro tahun 2007 di Depok

Peraturan Pemerintah RI No. 55 tahun 2007 tentang Pendidikan Agama dan Pendidikan Keagamaan

Radar Banten; Rubrik Utama, Program Buta Aksara Simpang Siur, edisi Senin 7 April 2008

Rizqon Halal Syah Aji, "Dampak .Covid-19 pada Pendidikan di Indonesia :Sekolah, Keterampilan dan Proses Pembelajaran, "SALAM: Jurnal Sosial \& Budaya Syar-I FSH UIN Syarif Hidayatullah Jakarta Vol. 7 No. 5 (2020),pp.395-402, DOI:10.15408//sjsbs.vi5.15314

Statistik Gender Bidang Pendidikan tahun 200-2004, BPS Pusat, Jakarta

Terhadap kegiatan pembelajaran Online di Sebuah Perguruan Tinggi Kristen Di Indonesia, http://doi.org/10.21009/PIP.341.1 Volume 34 Issue 1.

Tim Penyusun, (1989) Kamus Besar Bahasa Indonesia, Depdikbud Jakarta: Balai Pustaka

Undang-undang Dasar 1945

Undang-undang Sistem Pendidikan Nasional tahun 2002

Wicaksono, S R. (2012), Kajian pembelajaran Online Berbasis WIKI DI Lingkup Perguruan Tinggi, 